\title{
Ideal Theory after Auschwitz? The Practical Uses and Ideological Abuses of Political Theory as Reconciliation
}

\author{
Benjamin L. McKean, Ohio State University
}

Contemporary debates about ideal and nonideal theory rest on an underlying consensus that the primary practical task of political theory is directing action. This overlooks other urgent practical work that theory can do, including showing how injustice can be made bearable and how resisting it can be meaningful. I illustrate this important possibility by revisiting the purpose for which John Rawls originally developed the concept of ideal theory: reconciling a democratic public to living in a flawed world that may otherwise seem more of a home for catastrophe than justice. However, Rawls's account of reconciliation is flawed; because of his methodology, the realistic utopia he constructs as a source of hope can be used to defend an unjust status quo. By drawing lessons from Theodor Adorno's contrasting view of reconciliation after the Holocaust, I offer a more democratic method for political theory to offer sources of hope to the public.

W hy does political theory matter in a world of urgent and overwhelming injustice? Contemporary answers to this question often assume that theory should guide our response to injustice by directing us to particular actions. In this framework, the debate concerns whether ideal or nonideal theorizing is better suited to this task. Partisans of the former argue that, without an appropriate ideal, we will not know whether or not we are on the right path to justice (Simmons 2010); partisans of the latter contend that such ideals are uninformative about the practical choices we face today (Sen 2009). This underlying consensus that the primary practical task of political theory is directing action crucially overlooks how theories can shape attitudes toward what is possible in politics. As a result, the emotional and affective dimensions of responding to injustice are often marginalized, and imaginative reflections on possible futures are wrongly presumed to be practically inert. In this article, I seek to rectify these exclusions and argue that political theory can have practical force by showing how injustice can be bearable and resisting it can be meaningful, rather than by commanding any particular action. To do this, I revisit the practical purpose for which John Rawls originally developed the concept of ideal theory: to help reconcile a democratic public to living in a broken world that may seem more of a home for catastrophe than justice. Rawls was not alone in finding this task essential in the aftermath of World
War II and the Holocaust. Strikingly, both Rawls and Theodor Adorno recast the concept of reconciliation, employed by Immanuel Kant and G. W. F. Hegel to demonstrate the underlying rationality of human existence, to respond to the palpable irrationality of the twentieth century. As I will show, their accounts of reconciliation, which are in some respects mirror images of each other's, are flawed but nevertheless offer important lessons for how political theorists can respond to contemporary injustice.

Convinced that theodicy was impossible after Auschwitz, Rawls saw overcoming injustice not only as an organizational challenge but also as an affective one, since the prevalence of injustice can induce despair and lead us to doubt the possibility of ever achieving justice. If such doubts become pervasive within a democratic public, the consequences can be dire, as citizens abandon the values that sustain their coexistence. By describing a realistic utopia, ideal theory can reconcile the public and give its members the hope needed to sustain the long struggle against injustice. Crucially, rather than imagining ideal theory as the province of a special few with access to an obscure truth, Rawls conceives of reconciliation as properly having an essentially democratic character, addressing its audience as equally capable of reflecting on politics as professional philosophers. However, Rawls's account is notably flawed. While Rawls explicitly conceives of ideal theory as a political practice within a democratic society

Benjamin L. McKean (mckean.41@osu.edu) is an assistant professor of political science at Ohio State University, Columbus, OH 43210.

The Journal of Politics, volume 79, number 4. Published online Month XX, 2017. http://dx.doi.org/10.1086/692589

(C) 2017 by the Southern Political Science Association. All rights reserved. 0022-3816/2017/7904-00XX\$10.00 
that is not already well ordered, he also tries to construct his ideal theory from material he believes his audience already accepts. Yet, in a democracy characterized by unjust institutions, there are no facts or theories we should presume everyone accepts, and so, contrary to Rawls's avowed intentions, his methodology actually makes it much more likely that ideal theory will become ideological by turning certain facts about our unjust world into features of a purported utopia.

To rectify these problems, I turn to Adorno's contrasting defense of the practical affective import of philosophy after the Holocaust. Like Rawls, Adorno seeks to take the concept of reconciliation from its Kantian and Hegelian origins and make it adequate to a damaged world in which theodicy appears implausible. If Rawls can be said to offer a democratic conception of the audience for political theory but an undemocratic mode of addressing them, Adorno offers something like the reverse. On his view, we must go on living our own lives even amid catastrophic suffering, though doing so requires us to make ourselves somewhat cold and indifferent. Where Rawls seeks to banish this cynical indifference despite the persistence of the injustice that provokes it, Adorno suggests that the best way to preserve the hope of complete reconciliation under such circumstances is instead to take responsibility for making ourselves cold and so refuse to be entirely reconciled. This assumption of responsibility acknowledges the way theorists are themselves affected by injustice and productively highlights the way their thinking remains provisional and vulnerable to failure. Adorno's view thus chastens Rawls's, guarding against the temptation of declaring unjust arrangements ideal and keeping the space of political possibility open for more radical proposals. Yet, while Adorno's mode of addressing the public is egalitarian in foregrounding his own imperfection and fallibility, his conception of audience is not. An account that divides the world into cold theorists and suffering others lacks the conceptual resources to conceive of its audience as potential equal partners in organizing against injustice, making it unduly difficult to imagine undertaking cooperative political action. Consequently, I conclude by suggesting that we should pursue a more fully democratic theory of reconciliation that would find reasons for hope in our imperfect relations with each other.

\section{SEEKING RECONCILIATION AFTER KANT AND HEGEL}

Rawls's concern to reconcile a democratic public is not obvious from his official definitions of ideal and nonideal theory. Rawls describes ideal theory as concerning "what a perfectly just, or nearly just, constitutional regime might be like" assuming favorable conditions and strict compliance by (nearly) everyone with the principles of justice (2001a, 13). Nonideal theory, by contrast, relaxes those conditions to consider how to deal with individuals or peoples who do not comply or how to deal with unfavorable conditions in which "historical, social, and economic circumstances" make it difficult to achieve a well-ordered regime (Rawls 2001b, 5). Yet Rawls is clear that the practical role of ideal theory is so important that its content is conceived with that in mind, asserting that "The very content of the first principles of justice, in contrast with the content of derivative standards and precepts, is determined in part by the practical task of political philosophy" (1999a, 330). Despite this, Rawls's account of the practical task of reconciliation and how it shapes the content of his ideal theory has been overlooked. ${ }^{1}$ The task of reconciling us to our social world - a function, he notes, "stressed by Hegel in his Philosophy of Right (1821)"-leads philosophy to encourage its audience "to accept and affirm our social world positively, not merely to be resigned to it" (2001a, 3). Why is this a worthwhile aim? Strikingly, Rawls turns to Kant to explain the urgency of this task, suggesting, "If a reasonably just Society of Peoples whose members subordinate their power to reasonable aims is not possible, and human beings are largely amoral, if not incurably cynical and self-centered, one might ask, with Kant, whether it is worthwhile for human beings to live on the earth" (2001b, 127). Consequently, a brief account of these earlier thinkers - and what made their accounts seem impossible to accept after the Holocaustis essential.

Kant famously asks, "What may I hope?" because we often seem to need information beyond the ability of reason to know $(1989,677)$. In the first instance, this concerns reconciliation between nature and freedom; we cannot know theoretically that we are free, but we must make our freedom a "practically necessary presupposition" if we are to act at all (Kant 1996, 52). However, Kant can see that the freedom of many people is constrained by war and oppressive political institutions. What are reasonable hopes for enjoying freedom in the future given these grim circumstances? Kant argues that we should believe that humanity is inexorably progressing toward a world of republican states living in perpetual peace. Just as it is practically necessary for an individual to assume his own freedom in order to act, so too does Kant argue that we ought to adopt this view of progress for its practical necessity. If we see history as "the human race from period to period taking steps upward toward virtue and soon after falling back just as deeply into vice and misery," then we

1. A notable exception is Weithman (2009). Other practical tasks identified by Rawls include resolving political conflict by uncovering "some underlying basis of philosophical and moral agreement" (2001a, 2) and providing an orientation to political and social institutions. See Rawls (2001a, 1-5, 2007, 10-11). 
will look away in disgust (Kant 1997, 309). Such a lack of progress would mean that existing suffering and oppression is pointless, which would be "contrary to the morality of a wise creator and ruler of the world" (Kant 1996, 306). Consequently, we adopt this representation of history not on the grounds that it most accurately reflects our discernment of its objective features - they may seem to us an incomprehensible heap of happenings - but because it is more advantageous for overcoming nihilistic alienation. As Kant says, "Such a justification of nature - or rather perhaps of providence-is no mean motive for adopting a particular point of view in considering the world" $(1997,52)$. Thus, for Kant, to reconcile ourselves to the world as it is requires believing that we are progressing toward freedom and justice; to think otherwise would be to see life and action as a farce and to reject the possibility of an authentic theodicy.

With such an explanation in hand, we can make even the evils of wars tolerable, not only because we can be confident they will fade away but also because we can see them as contributing to progress. Kant tells us that "what affords this guarantee (surety) [of approaching perpetual peace] is nothing less than the great artist nature (natura daedala rerum) from whose mechanical course purposiveness shines forth visibly, letting concord arise by means of the discord between human beings even against their will" (1996, 331). In other words, we should see nature as guaranteeing that the exercise of human freedom contributes to progress even when individuals have no such intentions. This enables him to explain great evils because of the way that they can advance the cause of progress, writing, for example, "So long as human culture remains at its present stage, war is therefore an indispensable means of advancing it further" $(1997,232)$. One can see here the risk of such a progressive narrative serving ideological ends, as an unjust war could be defended in the name of perpetual peace. ${ }^{2}$ But Kant thinks this must be risked since the alternative - to refuse to believe in nature's guarantee that human freedom will progressively lead to perpetual peace - comes at too high a cost.

By contrast, Hegel does not see reconciliation as justified with reference to practical necessity or the future, but by the rationality of existing institutions. ${ }^{3}$ Key to Hegel's view is the famous dictum, "What is rational is actual; and what is

2. For a recent defense of Kant's view of hope, see Goldman (2012). For more on the role of reconciliation in structuring Kant's approach to politics, see Flikschuh (2000, 74-79).

3. Hegel does place his account of reconciliation within a narrative of historical progress, but it is an account of progress already achieved and so does not direct attention to the future. I put this to one side since Rawls attempts to offer an account of reconciliation in Hegel independent of these considerations. See Rawls (2000, 330). actual is rational," which he glosses with the phrase, "What matters is to recognize in the semblance of the temporal and transient the substance which is immanent and the eternal which is present" (Hegel 1991, 20). Hegel views the social world as having an underlying rational structure, which it is philosophy's task to comprehend. Reconciliation is the state of fullest rationality when institutions are arranged to respect the freedom of individuals and individuals recognize the rationality of existing institutions for doing so. Because the individual feels at home in the world and understands why he feels that way-indeed, understands why this very understanding is itself essential to feeling truly at home- he is most able to act within that world, confident of the meaning and appropriateness of his actions. Since Hegel believes that the world's rational structure is manifest in modern society, philosophy has the task of shepherding individuals to this awareness by alleviating their alienation. ${ }^{4}$

Near the close of the Philosophy of Right, Hegel observes, "The present has cast off its barbarism and unjust arbitrariness, and truth has cast off its otherworldliness and contingent force, so that the true reconciliation, which reveals the state as the image and actuality of reason, has become objective" (1991, 380). However, after Auschwitz, Rawls and Adorno understandably find it impossible to accept this. The world returned to barbarism with a vengeance-and with the state leading the way. Nor is Kant's faith in progress any easier to accept. That faith is deeply connected to his defense of the possibility of theodicy, which both Rawls and Adorno reject. Absent such faith, the ability to believe that the horrors of war can be understood to contribute to progress falters in the face of Auschwitz. Yet, while the Holocaust may block any straightforward adoption of Kant's view, it can also be understood to deepen the need that he responded to. If atrocities of such scale are possible, then we seem to have good reason to wonder if there is any point to contemplating political ideals when we cannot even stop barbarity. As the next section establishes, Rawls felt this worry acutely and consequently repurposed elements from Kant's and Hegel's accounts of reconciliation to defend the importance of ideal theory after Auschwitz.

\section{IDEAL THEORY AND THE HOLOCAUST AS PARADIGM INJUSTICE}

Rawls's own biography tellingly illustrates this affective challenge posed by gross injustice. By his own account, Rawls

4. For a useful discussion of Hegelian alienation, see Hardimon (1994). Notably, Rawls advised the dissertation from which Hardimon's book grew, and Rawls singles out this work as valuable secondary literature in Rawls (2000, 329). 
identified as "a believing orthodox Episcopalian Christian" early in his life and considered attending divinity school to become a minister. His undergraduate thesis at Princeton was a work of Protestant theology that analyzed the concepts of faith and sin and included a rebuke of social contract theory. The experience of World War II changed his views, however; Rawls reports that he "abandoned [his faith] entirely by June of 1945," transforming his interest in politics and justice. In an undated essay from the 1990s, Rawls reflected on his experience:

How could I pray and ask God to help me, or my family, or my country, or any other cherished thing I cared about, when God would not save millions of Jews from Hitler. When Lincoln interprets the Civil War as God's punishment for the sin of slavery, deserved equally by North and South, God is seen as acting justly. But the Holocaust can't be interpreted in that way, and all attempts to do so that I have read are hideous and evil. To interpret history as expressing God's will, God's will must accord with the most basic ideas of justice as we know them. For what else can the most basic justice be? Thus, I soon came to reject the idea of the supremacy of the divine will as also hideous and evil (Rawls 2009, 263).

Rawls's rejection of theodicy is clear and direct. The Holocaust is so monstrous that God must be rejected if He would permit such atrocities. Note how Rawls contrasts the Holocaust with the enormous evil of slavery, which in turn spawned the slaughter of the Civil War. While Rawls finds it possible to imagine a theodicy that would reconcile him to a world in which sin begat sin and injustice was met with injustice, the Holocaust shatters that ability to rationalize. ${ }^{6}$ So how is one to motivate moral action in a world that seems to be equally at home with genocide? One need not share

5. See Rawls (2009); for additional context, see Gregory (2007). Biographical information is drawn from Freeman (2007) and Pogge (2007). Biographical quotes in this paragraph from Rawls himself are from Rawls (2009, 261-63). Rawls's repudiation of his earlier faith there is so complete that he writes: "To the extent that Christianity is taken seriously, I came to think it could have deleterious effects on one's character" (265). Notably, as a graduate student, Rawls spent the summer of 1949 producing the index for Walter Kaufmann's book on Nietzsche.

6. One might also reject the theodicy Lincoln offered in his Second Inaugural and find in slavery itself sufficient grounds for questioning the justice of history. Even if the Civil War can be understood as a fitting punishment for the actions of whites in the North and South, what evil can African Americans have committed that could make their enslavement seem fitting to them?
Rawls's background theology to be moved to despair by the potential meaninglessness of our attempts to achieve justice when we cannot prevent horrific evils. Rawls's concern presents a deep problem for any theory that purports to guide action or invoke a better future.

How does Rawls address this problem of motivating action against injustice, after acknowledging that our world is one in which the scale of injustice can overwhelm us? Explicitly drawing on Hegel's Philosophy of Right, Rawls argues that the reconciliation ideal theory can provide is an essential precondition to effective political engagement with our social world. For Hegel, Rawls writes, "Political philosophy may try to calm our frustration and rage against our society and its history by showing us the way in which its institutions, when properly understood from a philosophical point of view, are rational, and developed over time as they did to attain their present, rational form" (Rawls 2001a, 3; see also Rawls 2007, 10-11). For Rawls, political philosophy should help confirm for us the meaningfulness of our political action and protect us from anxieties about futility and nihilism; good political theory should be able to make us feel more at home in the world. However, if it is the awfulness of the world that prompted our worry, how can we feel that the institutions of such a world are fundamentally connected to rationality?

In Joshua Cohen's interpretation, Rawls persists in a straightforward endorsement of the Hegelian slogan that what is rational is actual and what is actual is rational. As Cohen has it, Rawls endorses "a Hegelian Doppelsatz: we need to accommodate the ideal to the real because the real manifests the ideal" $(2009,59-60)$. This helps us to understand why some features of our world, such as the existence of reasonable pluralism, should not frustrate us. On the Rawlsian picture, while we might wish that everyone agreed with us completely, the free exercise of our moral powers is of great value to our freedom, even if it leads people to different conclusions that we must tolerate and our institutions must accommodate. But while this addresses some frustrations with society, the Doppelsatz cannot be the whole story for Rawls. Reconciliation cannot occur by seeing the reality of genocide as a manifestation of the ideal in any sense, yet neither can it be ignored. So how can ideal theory contribute to reconciliation after Auschwitz?

Rather than trying to reconcile us by identifying something ideal in such horror, Rawls suggests that ideal theory can sustain us by training our eyes on a distant but realistic utopia - a task that he identifies as "a variation of" Hegelian reconciliation (2001a, 4). Indeed, Rawls echoes Kant's orientation to a better future when he argues that "by showing how the social world may realize the features of a realistic 
utopia, political philosophy provides a long-term goal of political endeavor, and in working toward it gives meaning to what we can do today" (2001b, 128). Having seen that just institutions are achievable on earth, our world can seem more of a home to us. While critics have emphasized the practical and conceptual problems with identifying a long-term goal without considering the means for achieving it, they have largely overlooked the worry about political affect that motivates Rawls to envision such an ideal (cf. Geuss 2005; Wiens 2015). Rawls imagines a desirable future, because with it political philosophy can provide a warrant for political practice against the fear of meaninglessness and hopelessness through what Peter Brooks calls "the anticipation of retrospection" (1992, 23). Our political actions today appear meaningful by looking back on them from the perspective of an achieved realistic utopia; this perspective enables us to feel that our actions will have contributed to justice in a way obscured by our uncertain present. For example, envisioning a society in which Rawls's two principles of justice are fully realized can help corroborate the meaningfulness of working for more modest redistributive policies in the present. Reconciliation after Auschwitz thus becomes possible because we draw hope and comfort not from accepting institutions as they are, but from perceiving the possibility of their transformation.

Rawls is careful to note that the idea of a realistic utopia "establishes that such a world can exist somewhere and at some time, but not that it must be, or will be" (2001b, 127). This diverges from the philosophies of history that Kant and Hegel offer and raises the question: Why should this possibility matter to us? Rawls suggests two reasons. First, Rawls writes, "I believe that the very possibility of such a social order can itself reconcile us to the social world. The possibility is not a mere logical possibility, but one that connects with the deep tendencies and inclinations of the social world" (2001b, 128; emphasis added). This suggests that we care about a realistic utopia, because, with a proper understanding of our own society, we can hypothesize a relationship of historical continuity to a better future. Where the Doppelsatz suggests that some apparent misfortune already exhibits features of the better future, this approach suggests that we can identify progressive trends in society that give us reason to think that contemporary injustices will be overcome without suggesting that there is anything ideal or redemptive in those injustices themselves. Second, Rawls writes: "Political philosophy is realistically utopian when it extends what are ordinarily thought to be the limits of practicable political possibility and, in so doing, reconciles us to our political and social condition" (2001b, 11; emphasis added). This suggests a potentially different connection, since the future is represented as an extension of ordinary thought about the limits of possibility rather than of deep and perhaps unacknowledged social tendencies. Such a utopia can provide hope and solace not only because I individually believe it is possible but because its practicability is generally accepted, at least implicitly; I can more readily feel at a home in an imperfect society when I know that my hopes for the future are compatible with its conventional wisdom. However, while ordinary thought about political possibility may be an expression of the same deep social tendencies that justify hope, it may also express something different; in societies marked by injustice, ordinary thought can be habituated to regard deeply flawed institutions as the best that can be hoped for. In the next two sections, I explore these possibilities by turning to Rawls's method for constructing a realistic utopia - a method that relies on Rawls's conception of the audience that ideal theory is meant to reconcile.

\section{RAWLS ON THE CONSTRUCTION OF A REALISTIC UTOPIA}

To perform the work of reconciliation, a realistic utopia must offer a vision that is distant enough from our unjust present that it can plausibly be called ideal while also appearing sufficiently familiar that we can recognize it as connected to the world we inhabit. What would be a principled method for constructing a realistic utopia to perform this task? Rawls explicitly draws his method from what he identifies as the Rousseauvian strain in Kant, specifically from his interpretation of Rousseau's famous dictum that political philosophy should take "men as they are and laws as they might be" (2001b, 7 and 13). Following this slogan, Rawls rejects the idea that the indifference to suffering that made the Holocaust possible should lead us to believe that people are naturally evil or "incurably cynical and self-centered" (2001b, 127). Instead, Rawls gives an account of human nature as fundamentally reasonable - that is, capable of being motivated by moral reasons. In the Discourse on Inequality, Rousseau defended his view of human nature through a kind of imaginary natural history and introduced the methodology of this argument by writing, "Let us therefore begin by setting aside all the facts, for they do not affect the question" (1997, 132). It is not obvious that Rawls can do the same. Rousseau and Kant shared a belief in the possibility of theodicy that is unavailable to Rawls and unpersuasive for addressing a democratic public with a diversity of beliefs about religion and nature. Within the world, there is plenty of evidence that people act very badly indeed, so what licenses Rawls to assume that they will act justly in other circumstances?

Here, Rawls adopts Kant's strategy of making a practically necessary presupposition-now given a political twist and refracted through an injunction that the Holocaust must not 
take our hope, even when it has undermined faith. He writes: "We must not allow these great evils of the past and present to undermine our hope for the future of our society as belonging to a Society of liberal and decent Peoples around the world. Otherwise, the wrongful, evil, and demonic conduct of others destroys us too and seals their victory" (2001b, 22). That is, Rawls justifies his belief in the human capacity to be reasonable by highlighting the practical importance of adopting this viewpoint. The failure to adopt an appropriate viewpoint on human action could mean resignation and despair for the individual, but Rawls's worry is ultimately more political than existential; Rawls refers to "our hope" because he identifies the most important audience for reconciliation as the public. In particular, Rawls argues that the failure to believe that people naturally respond to moral reasons contributes to bringing about the cynicism and selfcenteredness it already proclaims as fact. Rawls asserts that the amorality of an unreconciled public can turn a cooperative, democratic society into an unstable power struggle-a situation he repeatedly identifies with the Weimar Republic that preceded Hitler's regime (Rawls 2007, 8-9; see also Rawls 1996, lix-lx). Such dramatic political stakes are not mere hyperbole, but methodologically essential if the presumption of human reasonableness is to be justified by appeal to practical necessity. Rawls makes this relation clear when he writes: "Our hope for the future of our society rests on the belief that the social world allows a reasonably just constitutional democracy existing as a member of a reasonably just Society of Peoples" (2001a, 11). Without believing in the realism of such a utopia, our hopes have no ground and the future simply will not look worth pursuingand so not only must political philosophy provide a realistic utopia to prevent that, it may invoke these practical effects as a justification for belief in utopian possibility.

The need to address this justification for reconciliation to the public shapes both the self-understanding of the political philosopher and the content of the realistic utopias she conceives. Rawls writes, "What is the audience of political philosophy? . . . Surely, in a democracy the answer to this question is: all citizens generally" $(2007,1)$. This audience must be addressed in a particular way; Rawls argues that the practice of political philosophy should be democratic in the further sense that "writers in political philosophy have no more authority than any other citizen, and should claim no more" $(2007,2)$. An account of reconciliation for democratic publics should in principle be acceptable to all; identifying an account of reconciliation with a partisan claim would be especially problematic, as it could serve to discredit realistic utopianism for partisans of other positions and reinforce cynicism. Moreover, because they are not authorities, po- litical theorists cannot appeal to superior expertise in their argument and ought to rely on claims that are already broadly accepted by a democratic public. In this fashion, the urgent practical task of reconciling a democratic public should guide a theorist in deciding what material from the existing world to use when constructing a realistic utopia that properly fulfills its practical aim.

This justification for Rawls's view of men as they are thus shapes his understanding of laws as they might be. Which facts about our unjust world can help us to see what institutions people would have in a more just one? How can we know what human conduct we need to accommodate in our realistic utopias and what can be dismissed as merely the product of our own benighted institutions? These are difficult questions, but the need to ensure the public's acceptance of the answers puts pressure on Rawls to risk as little uncertainty as possible in constructing his realistic utopia. Consider Rawls's ideal picture of international politics in The Law of Peoples. Rawls writes: "The specific conditions of our world at any time - the status quo-do not determine the ideal conception of the Society of Peoples" (2001b, 89-90; emphasis added), but it is a curious and much-remarkedupon feature of this realistic utopia that it closely resembles prevailing understandings of the world, including a World Trade Organization, a World Bank, and a United Nations (2001b, 42-43; see also Buchanan 2000). This should seem less curious in light of the methodology described above. No one can doubt the "realism" of institutions that already exist.

Rawls means for a utopia that is an idealized version of our world to seem acceptable and achievable to the public, but its very familiarity raises a question: If people in the future who share our nature act reasonably within institutions not unlike ours, why do we not already live in that world? For Rawls, it is not human nature, but the contingent flaws of existing political and social institutions that explain our failure to have realized our ideals. He writes: "The social system shapes the wants and aspirations that its citizens come to have. It determines in part the sort of persons they want to be as well as the sort of persons they are. Thus an economic system is not only an institutional device for satisfying existing wants and needs but a way of creating and fashioning wants in the future" (1999b, 229). Rawls means for this to support his claim that a just society will be stable, but its implications for own nonideal society are also important. An unjust social system profoundly shapes the character of the people who grow up under it and can explain their failure to respond reasonably. The existence of unjust institutions does not justify unreasonable or self-centered behavior, of course, but simply explains it, resolving the apparent contradiction between Rawls's presumption of our reasonable nature and 
the occurrence of the political catastrophes that make reconciliation so important in the first place.

However, this resolution points to a deep problem in Rawls's account. Rawls argued that a realistic utopia could be connected to the present and consequently meaningful for us in two ways: through the deep tendencies of the social world and through extending what are ordinarily thought to be the limits of practicable political possibility. Rawls seems to assume that these amount to the same thing, because of humanity's capacity to be moved by moral reasons. But Rawls's explanation of why we have failed to realize our ideals points to how these two can come apart when existing institutions are unjust, since those institutions shape the character and thereby the ordinary thoughts of those who grow up under them. Is a vision that extends the ordinary thoughts of an audience habituated to injustice likely to be wholly utopian? Or will it be so marked by injustice that calling it utopian inadvertently serves ideological ends?

\section{LEARNING "THE LESSON OF THE HOLOCAUST"?}

In seeking an ideal theory that can reconcile a democratic public divided by injustice, Rawls faces a dilemma. Rawls knows that our own society is riven by political disputes about the basis of public justification. He writes: "Our society is not well-ordered: the public conception of justice and its understanding of freedom and equality are in dispute. Therefore, for us - you and me - a basis of public justification is still to be achieved" (1999a, 355). Yet Rawls nevertheless addresses the audience for reconciliation as if it already lives in a realistic utopia, offering a view that purports to draw from a shared justificatory basis when it instead relies on premises that are deeply disputed within actual politics. By treating certain contentious claims as outside politics, such attempts at reconciliation may needlessly enshrine certain facts about the status quo as ideal when they are not. Rawls is aware of this danger. In a footnote, he notes: "The idea of political philosophy as reconciliation must be invoked with care. For political philosophy is always in danger of being used corruptly as a defense of an unjust and unworthy status quo, and thus of being ideological in Marx's sense. From time to time we must ask whether justice as fairness, or any other view, is ideological in this way; and if not, why not?" (Rawls 2001a, 4, n4; see also Rawls 1999a, 326, n4, and 2007, 10, 359-62). Reconciliation seeks to make us feel at the home in the world and thereby risks encouraging complacency; there is thus a standing danger that it may be used to defend a status quo that is not actually just. In this section, I will argue that Rawls's attempt to address a divided audience as though it were already well ordered leads him into precisely the trap that he sought to avoid.
So why does Rawls address the public in this fashion? Recall that Rawls's worry is that actual democratic politics can devolve into a tenuous and ultimately unstable balance of power between cynical competing interest groups unless individuals come to politics already reconciled, which prepares them to see others as reasonable and to give due consideration to their interests. Consequently, despite asserting that political theorists should be understood as citizens in a democracy like any others, Rawls also asserts that theory is a practice that happens outside politics, not within it. He states plainly: "Our answer to the question of whether a reasonably just Society of Peoples is possible affects our attitudes toward the world as a whole. Our answer affects us before we come to actual politics, and limits or inspires how we take part in it" (Rawls 2001b, 128, emphasis added; see also Rawls 2007, 7). There is a perfectly common sense element to this separation of theory and "actual politics"; to put theory at the heart of political life would be misguided aggrandizement. ${ }^{7}$ But the combination of Rawls's aspiration to provide an account that all can accept along with the necessity of reconciling them before they engage in politics leads to a stronger claim: what I will call the "priority thesis" that ideal theory can and should promote reconciliation by relying only on experiences, facts, and arguments that are themselves outside politics - or at least are not being actively contested within actual politics. To Rawls, looking for the resources to envision a realistic utopia within the experience of contentious democratic politics is a terrible risk, since to enter politics unreconciled could propagate cynicism and distrust with disastrous consequences. However, refusing this risk means he must construct a realistic utopia using claims that are already acceptable to a public shaped by existing unjust institutions. By setting the stakes of reconciliation so high in order to justify his presupposition of human reasonableness on the grounds of practical necessity, Rawls has boxed himself in. As a result, Rawls tries to guarantee reconciliation by having theorists address their audience employing only claims that partisans of all stripes accept, despite the

7. Rawls himself modeled this distance in his own life. Freeman reports $(2007,5)$ : "He regularly declined requests for interviews, and chose not to take an active role in public life. He conscientiously avoided celebrity status. Rawls believed that philosophers are normally misunderstood when they address the public, and that though philosophy has a major influence on political life, its influence is indirect, taking many years before it becomes a part of a community's moral consciousness." There are two notable exceptions to this avoidance. The first was his opposition to the war in Vietnam and his support for an effort to have the Harvard faculty endorse a reform of the military draft that would have made selection entirely by lot (see Pogge 2007, 19-22). The second came after his 1995 stroke, when he signed an amicus curiae brief to the Supreme Court in favor of the right to die, published as Dworkin et al. (1997). 
evident impossibility of this aspiration in the contemporary context.

If taken seriously as a methodological guideline, this priority thesis undermines the democratic credentials of Rawls's view in three ways: first, his view implicitly discourages theorists from acknowledging their own fallibility and reflecting on how they are influenced by the politics of an unjust society; second, the priority thesis limits the potential means for political theorists to address an audience, rendering it unnecessarily exclusive; third, his realistic utopia relies on contentious partisan claims while purporting to stand outside such disputes. These features all derive from the perceived need to respond to an unjust world while bracketing the disagreement that accompanies a disordered society. Taken together, they have the ideological effect of directing ideal theory away from confronting the scope and persistence of injustice's effects. In short, Rawls is right to conceive of the audience for political theory as a democratic public, but he is wrong in his assumptions about the way to address that public in its current state.

First, suggesting that theorists can work outside of politics stands in tension with his own account of the pervasive influence of institutions and the inevitable effects when those institutions are unjust. Consider how individuals are likely to be influenced by the context of unjustifiable racial and economic inequality, for example, as the recipients of undeserved benefits understandably struggle to rationalize their holdings (Mills 2015). Contestation is pervasive under such conditions, extending to judgments, doctrines, and factual matters, and there is no reason to think that professional intellectuals are immune from this. However, since Rawls seeks for ideal theory to guarantee reconciliation, acknowledging the provisional and fallible nature of the theorist's realistic utopia risks introducing a dangerous uncertainty, and so the theorist's own location within politics must be downplayed.

Second, the priority thesis leads to a needlessly narrow picture of how philosophers can address others. Seeking venues for deliberation that stand outside actual politics, Rawls suggests that other citizens could come across ideas from theorists in "editorials and discussions debating these ideas in newspapers and in journals of opinion" (Rawls 2007, 6). However, the contemporary media is itself hardly neutral or nonpartisan; the influence of party politics and the profit motive on the structure of communications is clear. Given the evident unreliability of informing the public through such methods, Rawls often ends up settling for the much more limited and elite audience that political theory typically addresses, particularly the judiciary. For example, he singles out "liberal writers in philosophy [influencing] the judges on a Supreme Court in a constitutional regime like ours" (Rawls
$2007,4)$ as one of the most powerful way for theorists to engage in politics. Such communication among elites may be effective, but addressing political theory exclusively to such a limited audience undermines his own more democratic aims.

The third major problem concerns the content of a realistic utopia constructed with the aim of reconciling a divided public. Consider again the strikingly familiar view of international politics Rawls describes as realistically utopian. In defending limits on the amount of global redistribution of wealth required in ideal theory, Rawls crucially relies on the disputed economic claim that "the political culture of a burdened society is all-important" for its development $(2001 \mathrm{~b}, 108)$; in other words, rich countries are not necessarily obliged to share their wealth with poor countries, since it is the culture of poor countries that is responsible for their poverty. Elsewhere he rather startlingly describes an Islamic people in his realistic utopia as resembling the state Hegel outlines in The Philosophy of Right and, in defending this suggestion from the charge of "baseless utopianism," he notes that an ideal theory must consider that "most Muslim rulers ... [have] sought empire and territory" (2001b, 75-78). These claims about economic development and Islamic leadership are about the institutions of our world, and they are obviously contentious; candidates for office today debate precisely these questions about the efficacy of foreign aid and the character of Muslim societies, for example. My point is not to take sides in these particular debates, but simply to point out that there are sides. Despite his aspiration, the facts on which Rawls relies in constructing and defending his realistic utopia are subject to dispute within actual politics rather than belonging to a set of shared premises that precede politics or that can be vindicated by shared justificatory standards.

Rawls's account faces these problems because, in response to features of our world that cause despair, it seeks to cultivate hopeful attitudes without acknowledging the persistence of the unjust structures that cause despair and oppression; the result is an attitude ill fitted to its full social context. A contrast with Hegelian reconciliation makes this clear. For Hegel, objective institutional arrangements were primary; to be subjectively reconciled without the right kind of actual social world was impossible or, as Marxists would later add, to be the victim of false consciousness. By contrast, Rawls's conception gives priority to achieving the subjective attitude of reconciliation as a precondition to the achievement of just institutions, since we must be reconciled in order to engage in effective political action. This difference is highlighted by what Rawls takes to be the most likely permanent threat to reconciliation. While Hegel acknowl- 
edged that poverty could form the objective basis of subjective alienation even in an otherwise reconciled world, Rawls sees fundamentalism as the most important form of alienation in an otherwise reconciled world - an attitudinal rejection of reasonability that he understands to be purely subjective and without any material or institutional basis. ${ }^{8}$

In seeking to protect hope, Rawls reifies attitudes to politics so that they cease to be appropriately responsive to their circumstances. Rawls's conception of reconciliation sprang from a deep experience of the singularity of the Holocaust and a proclamation that theodicy must be rejected because it is "hideous and evil" to try to bend atrocity into reason. When Rawls writes, "Some seem to think that this idea [of a realistic utopia] is a fantasy, particularly after Auschwitz" (2001b, 19), one cannot help but suspect that the Rawls who was 78 when The Law of Peoples was published was thinking of the 24-year-old Rawls who lost his faith. But while Auschwitz shook Rawls's faith in God, it apparently cemented his consequent belief in human goodness, as he writes: "The fact of the Holocaust and our now knowing that human society admits this demonic possibility, however, should not affect our hopes as expressed by the idea of a realistic utopia and Kant's foedus pacificum. Dreadful evils have long persisted" (2001b, 21). Rawls's practically necessary faith in human reasonability means that the Holocaust cannot tell us anything consequential about what attitudes to take up to humanity or human possibility; it can only tell us about our institutions. Thus, Rawls, who found efforts to rationalize and explain the Holocaust to be despicable, also asserts that "The lesson of the Holocaust is, rather, that a charismatic leader of a powerful totalitarian and militaristic state can, with incessant and rabid propaganda, incite a sufficient number of the population to carry out even enormously and hideously evil plans. The Holocaust might have happened anywhere such a state came to be" (2001a, 100). Rawls's claim is surely true, as far as it goes, but when it comes to taking the full measure of what the Holocaust can teach us, it is too limited. In the shift from theodicy to sociology, Rawls seems to have lost sight of the depth of the problem that he is addressing.

\section{ADORNO ON RECONCILIATION, COLDNESS, AND SUFFERING}

Let us return to the nature of that problem to consider another way of responding. Like Rawls, Adorno regarded the Holocaust as threatening to the meaningfulness of political

8. For Hegel on poverty, see Hegel (1991, 265-67); for Rawls on fundamentalism, see Rawls (2001b, 126-27). action and responded by appropriating the concept of reconciliation from Kant and Hegel to find sources of hope in its aftermath. However, where Rawls seeks to guarantee that despair at the Holocaust can be overcome in the name of preventing further barbarity, Adorno believes that a sounder method for employing reconciliation against barbarity can come from attending to our own implication in on-going suffering. In Rawls's methodology, the aim of ideal theory is palliative, but where Rawls soothes, Adorno aggravates. He reminds us that, in an unjust world, while it is practically necessary to feel somewhat at home, this should not direct our attention away from the unnecessary suffering that surrounds us. This suffering can force us to acknowledge our relation to existing injustice and the failure to make the world a home for all. But Adorno argues that this acknowledgement can itself help to fuel our hopes, revealing images of utopia even amid catastrophe.

Adorno's biographical and philosophical engagement with the Holocaust is better known than Rawls's. The son of a Jewish father who converted to Protestantism, Adorno fled Germany in 1934 and eventually moved to the United States in 1938 before returning to what was then West Germany in 1949. Unsurprisingly, the experience of exile from fascism marked Adorno deeply, and some of his bestknown writing concerns the challenge of living after such catastrophe, from war-time works like Dialectic of Enlightenment and Minima Moralia to his later magnum opus Negative Dialectics, written when he was a prominent public intellectual seeking to prevent the return of fascism in a country whose transition to democracy was, he believed, incomplete at best (Müller-Doohm 2005, 325-48). Like Rawls, Adorno rejects an entirely Hegelian reconciliation that reveals a world that is already rational, arguing that "the smallest trace of senseless suffering in the empirical world belies all the identitarian philosophy that would talk us out of that suffering" (1973, 203). For Adorno, the persistence of suffering is itself irrational, clear evidence that Hegel was wrong to suggest that the world had an underlying order that could make sense from both subjective and objective points of view. Instead, the Holocaust shows catastrophic suffering to be one of the defining characteristics of our time. The belief that complete reconciliation is now possible not only disrespects those who died and those who continue to suffer but also helps to perpetuate suffering by directing us away from attending to it. Adorno argues: "He who registers the deathcamps as a technical mishap in civilization's triumphal procession, the martyrdom of the Jews as world-historically irrelevant, not only falls short of the dialectical vision but reverses the meaning of his own politics: to hold ultimate calamity in check" (Adorno 1978, 234). Adorno thus shares 
with Rawls a belief that political thought must concern itself with preventing society from returning to barbarity, but he offers a different account of how thinking can do so.

Rawls proposes addressing an audience of democratic agents as though they are presently capable of universal agreement about matters central to reconciliation and, in doing so, places the theorist outside politics and brackets how existing unjust institutions shape the public. Adorno insists on the particularity of the theorist and places her firmly within political life, in part by attending to how her own life is marked by unjust institutions. Adorno thereby illustrates how political theory can help its audience endure injustice in a way that incorporates what Rawls leaves out. Adorno sketches this possibility when he asks: "Whether after Auschwitz you can go on living - especially whether one who escaped by accident, one who by rights should have been killed, may go on living. His mere survival calls for the coldness, the basic principle of bourgeois subjectivity, without which there could have been no Auschwitz; this is the drastic guilt of him who was spared" (1973, 36263). Living after the Holocaust requires that one inure oneself to atrocity just in order to go on, yet it is this very indifference to the suffering of others that made Auschwitz possible in the first place. Such coldness continues to facilitate injustice. In 1968, Adorno wrote: "In the security of America . . . it would be difficult to believe that Vietnam is robbing anyone of sleep. ... Whoever imagines that as a product of this society he is free of the bourgeois coldness harbors illusions about himself as much as about the world; without such coldness one could not live" (Adorno 2005, 274). Adorno frames the dilemma of reconciliation in an unjust world by asking, how can we be reconciled to a world of suffering when it seems that such reconciliation would be complicit with injustice?

To answer this question, we need to understand why Adorno believes the mere act of survival can make us guilty. One key is the claim that we collectively have the capacity to relieve much existing suffering and oppression. He writes: "Thanks to the present state of the technical forces of production no one on the planet need suffer deprivation anymore. Whether there will be further want and oppressionwhich are the same thing-will be decided solely by the avoidance of catastrophe through the rational establishment of the whole society as humanity" (2005, 144). Consider that the world's richest 92 people have as much wealth as the poorest 3.5 billion, making it easy to imagine that a feasible amount of redistribution could end global poverty (Hardoon 2015). Yet I cannot change these circumstances single-handedly, and cooperative group efforts to do so seem uncertain at best and may even appear futile. In the mean- time, to be at home in a world where suffering could be relieved but is instead tolerated or even intensified would be a false reconciliation, since it requires overlooking how the features of the world that ensure one's comfort also make it inhospitable to others. Despite this, we must find some way to live, even though to do so means accepting some accommodation with existing unjust institutions and inuring ourselves to on-going horror simply in order to take care of ourselves.

Where Rawls's account of utopian thinking directs us away from thinking about contemporary injustice lest it provoke cynicism about human nature, Adorno actually directs us to attend to the experience of distorting ourselves to live amid catastrophe. We can certainly hope that people are capable of acting reasonably, but doing so should not be premised on suppressing our cynical coldness entirely, since that is impossible to do in good faith while injustice and suffering persist.

Instead, though indifference is necessary if we wish to live our own lives, we should take responsibility for making ourselves cold and see this as a possible source of hope. That is a surprising suggestion since the labor of producing our indifference seems more like a source of despair, a sign that the world is so broken that we all must become similarly selfinterested in order to survive. Through the work of making ourselves cold, we are indeed "turning into something that makes us shudder," but Adorno says that the experience of coming to terms with this is "what compels us to philosophize" $(1973,364)$. Adorno argues that philosophy can serve as an expression of our discomfort with living in a world where our own survival depends on insulating ourselves from it. If it is honest, thinking that is rooted in this discomfort and seeks to envision a world without it must also acknowledge and take responsibility for one's own contribution to producing one's indifference. While pervasive coldness makes us similar, thinking about the possibility of reconciliation can thus individuate us when it compels us to take responsibility; I am the one who made myself cold in order to go on. Adorno's wager is that taking responsibility, even for such a damaging act, exhibits a form of freedom and individuality that is compelled and constrained by existing injustice, but which can also facilitate imagining a world of fuller freedom and individuality for all. Identifying this action as mine makes me guilty of a kind of complicity, but it also provides a trace of the freedom that would come when injustice has ended and complicity is no longer necessary.

For Adorno, when philosophy serves the very practical purpose of expressing disquiet with what an unjust world requires of its inhabitants, it thus also serves as a source of hope for reconciliation - a way out of the "catastrophic vi- 
cious circle in which human beings have an objective interest in changing the world" but in which the very institutions that must be changed have damaged us so much that we seem incapable of being the agents of that change $(2006,76)$. Adorno consequently placed such a great emphasis on popular education after the Holocaust that biographers describe him as "a ubiquitous presence in the media" in the 1950s and 1960s (Müller-Doohm 2005, 374). Convinced that people could develop their individuality by understanding the sources of their own coldness, Adorno suggested that his audience could taste freedom and find joy in "the power of the mind to retain its self-control in the face of the sorrow" caused by injustice $(2006,137)$. Thus, the spread of critical thinking could give hope for further social transformation and underwrite Adorno's belief that "Freedom can be achieved in reality. And in contrast to the entire dialectical tradition of Hegel and Marx, I would almost go so far as to say that actually this has always been possible, that it has been possible at every moment" $(2006,181)$. In order to realize that utopian possibility, though, we first need to realize our guilt; then, Adorno argues, "Given the way the world is organized, even the simplest demand for integrity and decency must necessarily lead almost everyone to protest" $(2006,167)$.

Suggesting that we can draw an image of freedom from our own discomfort with injustice gives Adorno's account of reconciliation a more inward and self-reflective character than Rawls's. This helps it avoid the latter's methodological need to construct a utopia from the beliefs of a public habituated by injustice, but it also generates its own problems. For example, it famously never led Adorno himself to public protest, which suggests that his account of reconciliation may not readily facilitate political action. Indeed, Adorno himself became the target of protests after he asked the police to remove students who were briefly occupying the offices of the Institute for Social Research in January 1969 (Müller-Doohm 2005, 464-65). Adorno's relationship to political action is thus ambivalent, as suggested by how he can only "almost go so far as to say" that freedom is possible. On the one hand, he praised the student activists for having "interrupted the smooth transition to the totally administered world" by, among other measures, opposing the emergency laws supported by the Grand Coalition of major German parties (Adorno and Marcuse 1999, 136); on the other hand, he found even signing petitions objectionable, "because in their inevitable desire to have a political impact, they always contain an element of untruth or presuppose a knowledge of specific circumstances" (Müller-Doohm 2005, 414). This ambivalence has many sources, but for my purposes, the most important is the way that Adorno's theory of reconciliation lacks any grounds for finding sources of hope in other people or our relationship to them. In particular, Adorno's account of suffering and self-imposed indifference provides no tools for imagining equal cooperative relations. Instead, it lends itself to an inegalitarian conception of the audience for reconciliation as suffering victims addressed by guilty theorists. This is doubly anti-democratic: on the one hand, it implies a philosophizing elite that does not experience oppression directly, though their indifference facilitates it in others; on the other hand, it also implicitly removes the agency of others by presenting them primarily as suffering victims. Adorno even goes so far as to say that because he sees the executioners of Auschwitz "under the spell of unfreedom," he thus "conceives of them as victims and not just as murderers" $(2006,203)$. But seeing others as either victims of, or complicit with, oppression (or both) does not facilitate treating them as equal partners in political action. One can see this at work in Adorno's practical suggestions for popular education, like his proposal for "mobile education groups" that would travel from cities to promote the "debarbarization" of the countryside $(2005,196-97) .{ }^{9}$ The presumption that urban educators have nothing to learn about suffering and utopia from rural residents is symptomatic of the danger with this conception of reconciliation's audience. Like Rawls's, Adorno's effort to offer sources of hopes for a future of justice and freedom falls short. Nevertheless, as I discuss in the next section, Adorno's account offers important lessons for developing a more democratic mode of addressing political theory to a public suffering injustice-one that can better avoid the ideological trap Rawls fell into.

\section{THINKING UTOPIA MORE DEMOCRATICALLY}

Rawls's aspiration to guarantee that reconciliation occurs before political engagement undermines the democratic nature of his view by obscuring the effects of existing injustice on the theorist herself and on the democratic public, which was addressed as though it was already well ordered. Adorno's account argues that we can find hope in taking responsibility for our damaging accommodations to such injustice, but it has difficulty moving from this individualizing moment to collective action-despite insisting on the possibility and desirability of this passage. What is needed is a theory that avoids these traps by conceiving of both a democratic audience for reconciliation and a democratic mode

9. Adorno engages in a rare bit of understatement when he writes of this condescending proposal: "I am not ignoring the fact that such people would make themselves liked only with great difficulty" (2005, 196-97). For a defense of Adorno on popular education, see Mariotti (2014). 
of addressing that audience. In closing, I discuss three features of such a fully democratic theory of reconciliation amid injustice: first, acknowledgement of the inevitability of disagreement; second, acceptance that philosophy is itself a political practice that may fail; third, seeing our relations with others as sources of hope, which in turn requires ensuring that our utopias include them. Such democratic reconciliation is necessarily plural and provisional; while our sources of hope can differ, we should all be prepared to revise our utopias when we find that they preserve the causes of others' suffering.

First, theorists who seek to reconcile democratic publics need not avoid disagreement, even on fundamental matters. In this chastened form, utopian thinking is not offered as a guaranteed solution to despair, and, since it no longer needs to ensure success for all, it can drop Rawls's requirement that it employ only facts beyond dispute in favor of acknowledging that some of its premises are provisional, nonideal, or disputed within actual politics. This does not mean that utopian thinking should become self-consciously sectarian or renounce its ambitions to address a public. Rawls rightly observes that, when political theory serves a democratic purpose by identifying reasons to believe in the possibility of achieving justice, its character should be shaped by the audience it addresses. However, because he fails to account for the disordered nature of a public structured by injustice, Rawls offers an overly narrow view of what kinds of address are democratically appropriate today. For example, in the context of a market economy characterized by distributive injustice, it can be effective to speak from one's own perspective without trying to tailor one's presentation to what one imagines would comfort an audience. Reflecting on the success of books like Dialectic of Enlightenment, Adorno wrote that his works "were written without practical intentions and nonetheless exercised some practical influence. That influence came from the fact that in a world where even thoughts have become commodities and provoke sales resistance, no one could suppose when reading these volumes that he was being sold or talked into something" (2005, 277; "sales resistance" is originally in English). Given a social world in which texts circulate as commodities and news is transmitted for profit, Adorno attributes the enduring appeal of his thought to a lack of apparent intention to be practically effective. Of course, such an approach has its own costs; just as Rawls's view risked charges of being ideological by envisioning utopias that resembled the present too closely, theorizing that makes no concessions to the public risks charges of navel-gazing and undemocratic inaccessibility. Because we do not live in a well-ordered society in which there is general endorsement of shared standards of public justification, any utopian conception must be offered to the public with the hope that it may inspire hope. But there is no guarantee that it will be received that way; in that sense, it is a political action like any other, a risk.

Rawls assumes that we will not take such a risk without some reason to believe that things could turn out all right and consequently believes that presupposing human reasonableness is practically necessary. However, one can share Rawls's worry about the potential meaninglessness of resisting injustice without believing that it must be assuaged before political action begins. Instead, members of a democratic public can recognize that political action is always ongoing and they are already taking a risk by living in society. Our position is not that of a person on a diving board who needs encouragement in order to take the plunge; we are more like a group on a life raft that needs a reason to believe dry land can be reached if most of the people on the raft can figure out how to row in the same direction. In this spirit, Adorno reminds us that "in the final analysis thinking is itself a form of behavior" $(2001,4)$, shaped by its environment like other behavior; as a consequence, he suggests, "We need to hold fast to moral norms, to self-criticism, to the question of right and wrong, and at the same time to a sense of the fallibility of the authority that has the confidence to undertake such self-criticism" (Adorno 2001, 169).

This enables a more democratic form of address than attempting to guarantee reconciliation; political theorizing that acknowledges its own fallibility can make it easier for the theorist to address her audience as equals. On this view, since reasons for hope need not be provided before politics begins, their effectiveness can be enhanced rather than undermined by acknowledging that we are all in the same boat, as it were, and that our theorization of reconciliation may be affected by the unjust institutions we live in.

Finally, a more democratic view of reconciliation would find hope for a just world in our relations with others. Adorno's view makes theory into a practice, but at the cost of making all other practice seem impossible because of how it orients his audience to regard others as suffering victims to be pitied. Not only does this attitude imply a hierarchical relation, but, as Adorno himself notes, such compassion "tacitly maintains and gives its sanction to the negative condition of powerlessness in which the object of our pity finds himself" (Adorno 2001, 173). The focus on suffering thus depoliticizes and naturalizes unjust relations that ought to be contested and shown to be contingent. By contrast, Rawls's account asserts the political equality of theorist and audience, but it sees this relation expressed by an impossible agreement among them; disagreement about ideals becomes evidence of the futility of politics. A better approach would 
see existing relations as imperfectly instantiating our equality and as sources of hope for its fuller realization. By giving us hope for achieving justice in the future, reconciliation is meant to help us live together in an imperfect democratic society, so we must be especially alert when we are told that the utopia that comforts us also preserves within it features that would make that society inhospitable to others. For example, in discussing the list of contingencies that his principles of justice correct for, Rawls says that race and gender are not included because "we are mainly concerned with ideal theory" (2001a, 65). This suggests that ideal theory is not informed by race and gender, but only by their absence and purported irrelevance. But Rawls's assurance here is contestable; many find sources of hope and even images of utopia in the solidarities formed around these identities. Even if such solidarities are partly a product of existing inequality and would be unnecessary in a fully just society, experiences born of injustice can nevertheless inform our ideals, as Adorno showed. Since people are differently situated with respect to unjust institutions, it should not surprise us when others propose sources of hope we were not otherwise able to perceive. Indeed, we might find hope for justice precisely in the ability of others to show us forms of meaningful political action we would otherwise overlook.

Rawls does not consistently exhibit this blindspot toward the potential for political experiences to shape our utopias. $\mathrm{He}$ argues that the religious wars in the wake of the Reformation eventually led to a new way of living organized around toleration. Rawls describes this as "the discovery of a new social possibility" (2001a, 197), and he gives no reason to think that further new possibilities could not be discovered. I want to close by suggesting that Rawls's failure to treat the Holocaust as a new and terrible social possibility hampers his effort to offer a persuasive practical defense of political theory in its wake. His determination to guarantee reconciliation before we enter politics leads him to claim that, for practical purposes, we already know all we need to know about human possibility. But to close ourselves off from discovering new possibilities, good and bad, needlessly curtails the potential for radical critique and blocks us from confronting some urgent sources of despair. To be more consistent and democratic defenders of political theory amid injustice, we should embrace a conception of reconciliation that acknowledges that our realistic utopias are not fully ideal but rely upon the kind of nonideal and disputed understandings that are available to us within our existing, unjust social world. Since we cannot guarantee getting it right in advance, we should be ready to alter the utopias that give us hope when others tell us that our ideals preserve the causes of their suffering or exclude the sources of their joy.

\section{ACKNOWLEDGMENTS}

The author thanks Dana Howard, Charles Beitz, Derek Bowman, Julie Cooper, Stephen Macedo, Jan-Werner Müller, Jennifer Pitts, Ethan Porter, and James Lindley Wilson, as well as audiences at Georgetown University, University of Chicago, York University, the American Political Science Association, and the Western Political Science Association.

\section{REFERENCES}

Adorno, Theodor. 1973. Negative Dialectics. Translated by E. B. Ashton. New York: Continuum.

Adorno, Theodor. 1978. Minima Moralia: Reflections from Damaged Life. Translated by E. F. N. Jephcott. New York: Verso Books.

Adorno, Theodor. 2000. Introduction to Sociology. Edited by Cristoph Gödde and translated by Edmund Jephcott. Stanford, CA: Stanford University Press.

Adorno, Theodor. 2001. Problems of Moral Philosophy. Edited by Thomas Schröder and translated by Rodney Livingstone. Stanford, CA: Stanford University Press.

Adorno, Theodor. 2005. Critical Models: Interventions and Catchwords. Translated by Henry W. Pickford. New York: Columbia University Press.

Adorno, Theodor. 2006. History and Freedom: Lectures, 1964-1965. Edited by Rolf Tiedemann and translated by Rodney Livingstone. Malden, MA: Polity.

Adorno, Theodor, and Herbert Marcuse. 1999. "Correspondence on the German Student Movement.” Translated by Esther Leslie. New Left Review 233:123-316.

Brooks, Peter. 1992. Reading for the Plot: Design and Intention in Narrative. Cambridge, MA: Harvard University Press.

Buchanan, Allen. 2000. "Rawls's Law of Peoples: Rules for a Vanished Westphalian World." Ethics 110 (4): 697-721.

Cohen, Gerald Allan. 2008. Rescuing Justice and Equality. Cambridge, MA: Harvard University Press.

Cohen, Joshua. 2009. "Moral Pluralism and Political Consensus." In Joshua Cohen, Philosophy, Politics, Democracy: Selected Essays. Cambridge, MA: Harvard University Press, 38-60.

Dworkin, Ronald, Thomas Nagel, Robert Nozick, John Rawls, T. M. Scanlon, and Judith Jarvis Thomson. 1997. "Assisted Suicide: The Philosophers' Brief." New York Review of Books 44 (5): 41-47.

Flikschuh, Katrin. 2000. Kant and Modern Political Philosophy. New York: Cambridge University Press.

Freeman, Samuel. 2007. Rawls. New York: Routledge.

Geuss, Raymond. 2005. Outside Ethics. Princeton, NJ: Princeton University Press.

Goldman, Loren. 2012. "In Defense of Blinders: On Kant, Political Hope and the Need for Practical Belief" Political Theory 40 (4): 497-523.

Gregory, Eric. 2007. "Before the Original Position: The Neo-orthodox Theology of the Young John Rawls.” Journal of Religious Ethics 35 (2): 179-206.

Hardimon, Michael. 1994. Hegel's Social Philosophy: The Project of Reconciliation. New York: Cambridge University Press.

Hardoon, Deborah. 2015. Wealth: Having It All and Wanting More. Oxfam Issue Briefing. Oxford: Oxfam International.

Hegel, G. W. F. 1991. Elements of the Philosophy of Right. Edited by Allen W. Wood and translated by H. B. Nisbet. New York: Cambridge University Press.

Kant, Immanuel. 1996. Practical Philosophy. Edited by Mary J. Gregor. New York: Cambridge University Press. 
Kant, Immanuel. 1997. Kant: Political Writings. 2nd ed. Edited by Hans Reiss and translated by H. B. Nisbet. New York: Cambridge University Press.

Kant, Immanuel. 1998. Critique of Pure Reason. Edited and translated by Paul Guyer and Allen W. Wood. New York: Cambridge University Press.

Kant, Immanuel. 2005. Notes and Fragments. Edited by Paul Guyer and translated by Curtis Bowman, Paul Guyer, and Frederick Rauscher. New York: Cambridge University Press.

q8

Mariotti, Shannon L. 2014. "Adorno on the Radio: Democratic Leadership as Democratic Pedagogy." Political Theory 42 (4): 415-42.

Mills, Charles W. 2015. "Global White Ignorance.” In Matthias Gross and Linsey McGoey, eds., Routledge International Handbook of Ignorance Studies. New York: Routledge, 217-27.

Müller-Doohm, Stefan. 2005. Adorno: A Biography. Translated by Rodney Livingstone. Malden, MA: Polity.

Pogge, Thomas. 2007. John Rawls: His Life and Theory of Justice. Translated by Michelle Kosch. New York: Oxford University Press.

Rawls, John. 1996. Political Liberalism. New York: Columbia University Press.

Rawls, John. 1999a. "Kantian Constructivism in Moral Theory" In Samuel Freeman, ed., Collected Papers. Cambridge, MA: Harvard University Press, 303-58.

Rawls, John. 1999b. A Theory of Justice. Revised ed. Cambridge, MA: Harvard University Press.
Rawls, John. 2000. Lectures on the History of Moral Philosophy. Edited by Barbara Herman. Cambridge, MA: Harvard University Press.

Rawls, John. 2001a. Justice as Fairness: A Restatement. Edited by Erin Kelly. Cambridge, MA: Harvard University Press.

Rawls, John. 2001b. The Law of Peoples; with "The Idea of Public Reason Revisited. Cambridge, MA: Harvard University Press.

Rawls, John. 2007. Lectures on the History of Political Philosophy. Edited by Samuel Freeman. Cambridge, MA: Harvard University Press.

Rawls, John. 2009. A Brief Inquiry into the Meaning of Sin and Faith: with "On My Religion". Edited by Thomas Nagel. Cambridge, MA: Harvard University Press.

Rousseau, Jean Jacques. 1997. The Discourses and Other Early Political Writings. Edited and translated by Victor Gourevitch. New York: Cambridge University Press.

Sen, Amartya. 2009. The Idea of Justice. Cambridge, MA: Harvard University Press.

Simmons, A. John. 2010. "Ideal and Nonideal Theory." Philosophy and Public Affairs 38 (1): 5-36.

Weithman, Paul. 2009. "John Rawls and the Task of Political Philosophy." Review of Politics 71 (1): 113-25.

Wiens, David. 2015. “Against Ideal Guidance.” Journal of Politics 77 (2): 433-46. 